\title{
Three In One: Character Building And Academic Achievement With The Making Of Game Religion Multimedia Vocational School
}

\author{
H.Suhada ${ }^{1, a^{*}}$, Ferry Sudarto $2, b$ \\ ${ }^{1}$ Information Systems Department, ${ }^{2}$ Computer Systems Department, ${ }^{1,2}$ Raharja University JI.Sudirman,Banten,Indonesia, \\ asuhada@raharja.info; bferry.sudarto@raharja.info; \\ ${ }^{*}$ Corresponding Author \\ Whatsapp number: [081385743781]
}

How to Cite : Suhada, H., Sudarto, F. (2019). Three In One: Character Building and Academic Achievement with The Making of Game Religion Multimedia Vocational School. International Journal for Educational and Vocational Studies, 1 (6), 627-631

\section{ARTICLE HISTORY}

Received: 2 June 2019

Revised: 13 July 2019

Accepted: 7 September 2019

\section{KEYWORDS}

Character Development; Games Making;

Vocational School;

Improving Grades;

\begin{abstract}
Cases of student brawling, pornography to drug use by students are still concern today. Meanwhile, concerns about the quality of education in our country are increasing because the influence of technology is growing rapidly but it is not being used to the fullest for learning needs. Therefore we need solutions to improve the quality of learning by using information technology. Vocational high school multimedia study program offers the solution of culturally charged religious games, religious education and expertise. Making this religion game was directed by a multimedia productive teacher assisted by both religious and Indonesian Language teacher because the production of religious video game is the result of combining religion, narration and video game making skills. Video game religion can begin with an observation of social and religious life in schools or homes. Literacy can be done to help giving new ideas and value to character, morals and religion. Through the manufacture of religion games, it is expected that students interchange every existing role while learning religion. In addition to video games production can enhance students' skills and accomplishments in multimedia majors. The study set out to describe the creation of a game of religion that features the values of character education and Indonesian Language education in multimedia skills programs and make an attractive learning model.
\end{abstract}

This is an open access article under the CC-BY-SA license.

\section{INTRODUCTION}

The need of character education in the education world has become a weapon in order to prevent current aberration. Law number 20 of 2003 concerning the National Education system in Article 3, mentioned that the national education serves to develop capabilities and establish dignified national character and civilization in order to enrich the life of the nation. According to Charlie $(2002 ; 3$, "character education is an effort to help students understand, care, and behave according to the ethical values prevailing in society (Charlie, 2002:3)" Looking at the foregoing, precise solutions are needed both short and long-term in order to make improvements in positive direction of inculcating moral values and motivation in students. In order that implementation of education in schools work well, the ministry makes school manuals as technical guidelines in implementing character education in schools (Agus Wibowo, 2012: 44-45). Some of the schools' efforts to instill character values are by creating a school environment that reflects cultural character through the vision of a mission and school program. One of the lessons that students are interested in is the visual audio contained in the story board, the story script and games. Game narratives can act as reflection of the contemporary social-cultural discourse (Kristiadi DP et al, 2019). Production games featuring characters, creating a scenario and playing them are included in the types of activities that can improve learning achievement as stated by (Sardiman, 2006:96) can be classified as follows ; 1) the visual activities, which included in reading , watching, image of experimental demonstration, other jobs. Rossi and Breidle (1996) in the Sanjaya (2012:204) states that the learning media is the entire volume and material that can be used for educational purposes. Such as radio, television, books, newspapers, magazines, etc. The role of the media in teaching process can be placed as a tool to clarify teaching materials when the teacher delivers the lesson (Sudjana and RIvai, 2011: 60). Digital game itself as structured or semi-structured activity using all multimedia elements (text, sound, images, graphic arts, animation, and video)to enhance the performance of the 
game in presenting the games, fun, and entertainment which makes it usually done for fun. But it can also be used as an educational media to create interactive learning (Ririn DA, et al, 2015; Warnars HLHS, 2008). The ideas of the narrative can come from real life and it is influenced by the players especially if the narrative structure is based on the player's decisions. Therefore, it can be said that the narrative of the game can act as a reflection of contemporary socio-cultural discourse (Kristiadi DP, 2019). With the making of religion games, students will experience and evaluate themselves and will continue to be moved to behave well, honest, polite and $\mathbf{a}$. motivated to achieve.

\subsection{Religion Video Game,Character Education Religion Video Game}

Video games are defined as digital games played on the television or computer screen (Richard EF,2014). It is also described as a digital system with the following features: interactive and reactive properties, volatile markings and variable displays, dual sensory, and semiotic channels also network capabilities[Frank GB,2016]. But in the real game field, further expansion is needed o include serious aspects (advanced goals such as specialized knowledge training) (K.Salen and E. Zimmeran, 2014). For example, in game based learning, approaches like computer-based evaluation have been developed (DP Kristiadi, et al, 2019). Players will experience something called Gameplay Experience (GX) when they play their game (H.L.H.S. Warnars, 2008). GX is made during the process of player interaction, which these interaction have a purpose to provide motivating and enjoyable experience for players (FranK GB .2016). User Interface (UI) is everything designed to be an information tool, in which users can interact with (DP Kristiadi, et al, 2017) this include to the display, screen, keyboard, mouse, and desktop (DP Kristiadi, et al, 2017). It is also how users interact with the application or the website(Kristiadi, et all, 2017). This growth of dependency has led many companies to focus on web and mobile apps to place higher priorities on the UI to improve the EU as a whole(K. Hinckley, K. Yatani, et al, 2017). Meanwhile, the user experience (UX) is an art of product design planning, so the interaction with the product will be as large as possible (Kristiadi DP, et all, 2017). This includes interactions with the end user in several IT system including interfaces, graphics and designs. Both of these elements are very important for the product and work together. But despite their professional relationships, the role itself is quite different, referring to very different parts of process and discipline designs(Frank GB,2016).

Richard E.F. notes that there are three general religious terms (Richard E.F, 2014): Belief in God or group of Gods. An organized system of belief, ceremony, and rules used to worship God or a group of Gods. Importance, belief, or activity that is very important for a person or group. The third term is the most commonly used in religious video game.
Religion in video games is expressed by the elements of rules and religious teachings in it. To find religious elements in a video game, we can analyze these elements (Ririn DA, 2015; Warnars HLHS, 2008): 1. Game Narration. The narrative is stated as an oral or written account of the connected event; a story (Robert MG, 2012). 2. Aestethics. Building architecture, landscape, religious icons or symbols in a game can indicate the religious elements inside the game as it becomes the game resources to represents certain religion.

\section{Character Education}

Character is disposition, traits, moral, or personality of a person formed by the intercession of the various virtues that are believed and used as a foundation for ways of looking, thinking, behaving and acting (Ministry of National Education (2010:3)). Character education is a system of implanting character vales on a school citizen that consists of a component of knowledge, consciousness, or willingness and actions to implement those values. Implementation of character education is also concern in 2013 curriculum, it can be seen from the structure of the 2013 curriculum that contains subjects of Religion and Character.

To implement character values properly in school by giving a knowledge of values and norms so that students can feel positive effects of the values and students are being encouraged to internalize the value of the character impermeable to their everyday actions. (Lickona, 2011:70-74).

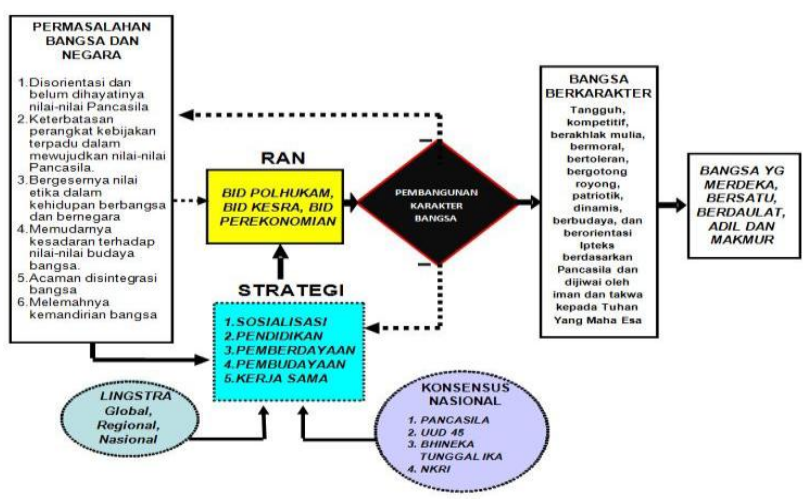

Figure 1. Strategies implementation of character

(Source: The Ministry of National Education, 2011:2)

The enforcement of character integration into education has general principles such as: (1) To not change the current educational system, (2) To not change the curriculum, (3) Learning uses the principles of learning to know, learning to learn, learning to be, and learning to live together, (4) carried out contextually so that there is a link between the education and the real needs of the students (Wagiran,2010).

\section{METHODS}

\subsection{Data Collecting Techniques}

The research began by looking at mid students' grades. Post test, Question and Answer with students about 
understanding constraints on theories or practices. The findings were recorded by researchers who subsequently obtained precise methods based on difficulties and students' characteristics. The idea of video games begins with students' problems of character both inside and outside the classroom. It comes from speech and decency also honesty. Then the teacher discussed how to solve problem. Based on the result of studies, some may conclude that: 1) students are spending a lot of time playing games and are thus: Audio and Visual subjects get a satisfactory average score but Indonesian Language and religious score is lacking. Students who have good grades in visual audio subjects tend to have poor grade in both Indonesian Language and Religious subjects (academic behavior and grades). 3) Advances in technology are not being expended to the fullest extent. Next, the researchers try to piece together three subjects by taking one lesson as a mobilize. Subject taken to make the religious games was the Audio-Visual. This audio-video subject was drawn for 1) it has a good average student score 2) it can be filled with Indonesian Language and religion lessons. 3) The students are free to express and creative using the technological media.

\subsection{The Data Analysis Technique}

Data derived from the study result will be presented in score and a percentage of the earnings

Description :

KB : The completeness of leaning

$\mathrm{S}$ : Score

TS : Total Score

( Trianto; 2011)

To see a percentage of vocational learning students use a percentage formula, which is:

$$
\%=\frac{\mathbf{A}}{\mathbf{B}} \quad \mathbf{K B}=\frac{\mathrm{S}}{\mathrm{TS}}
$$

$\% \quad$ : Students' percentage

A : Number of students that complete

B : Total number of students (Trianto : 2011).

\subsection{Design Model}

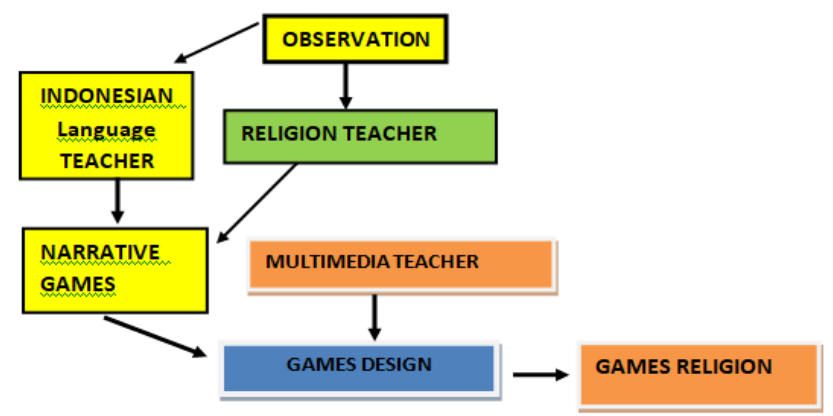

\subsection{Description Model}

Tabel 1. Frame Explanation

\begin{tabular}{|c|c|}
\hline Activities Frame & Description \\
\hline $\begin{array}{l}\text { A. Developing } \\
\text { Research } \\
\text { Instrument }\end{array}$ & $\begin{array}{l}\text { 1. Teacher in Indonesian Language, Mutimediaand Reigon } \\
\text { provide an overview of the assessment of each lesson. } \\
\text { 2. Make work steps and assignments based on the lesson } \\
\text { 3. Plans of each teacher. }\end{array}$ \\
\hline $\begin{array}{l}\text { B. Convey filmmaking } \\
\text { activities and the } \\
\text { practical value for } \\
\text { each field of study } \\
\text { to the students. }\end{array}$ & $\begin{array}{l}\text { 1. Indonesian Language Teacher: } \\
\text { a. Gives direction aboutmaking the manuscript scenario } \\
\text { and writing procedure using standard and correct } \\
\text { Indonesian Language. } \\
\text { b. Scenarios and script assessment are used as a score } \\
\text { for. Indonesian Language practice. } \\
\text { 2. Audio Visual Multimedia Teachers } \\
\text { a. Gives direction making story boards, taking pictures } \\
\text { and sentiments. } \\
\text { b. Story board assessment, picture taking, senfopents, } \\
\text { re repeated practice of audio visual lessons. } \\
\text { Religion Teacher } \\
\text { a. Gives direction about the contents of the film in the } \\
\text { form of honesty, responsibility, caring, religious, } \\
\text { politeness, hard-working, and independence. } \\
\text { b. The assessment of the contents of the film in the } \\
\text { form of honesty, responsibility, caring, religious, } \\
\text { politeness, hard-working, and independence } \\
\text { becomes the score of student's practice for } \\
\text { religion studies. }\end{array}$ \\
\hline $\begin{array}{l}\text { C. Steps to make } \\
\text { film }\end{array}$ & $\begin{array}{l}\text { Students } \\
\text { i. Divide into groups ( } 2 \text { groups on each class) } \\
\text { ii. Make a film scenario and propose it to the } \\
\text { Indonesian Language teacher } \\
\text { in. Proposing a scenariothat has been agreed to the } \\
\text { religion teacher to find out the content of moral } \\
\text { values and motivation. } \\
\text { Create story boards and determine the location to } \\
\text { the audio-visual teacher. } \\
\text { iv. The making of the games is supervised and } \\
\text { v. directed by Multimedia teachers. }\end{array}$ \\
\hline
\end{tabular}

\section{RESULTS AND DISCUSSION}

Report Score (Tabel 2) it can be seen that the development of the learning obtained by the students while given a pre (theory) has a tendency to average score: Indonesian Language $=68.1$ (6 students did not pass), Audio Visual= 88.63 (2 students did not pass), Character Biulding $=77.59$ (9 students did not pass). Students who passed or got passed the limit score $75-10$ on the pre-acts are Indonesian Language $=70.8 \%$, Audio Visual $=91.7 \%$ and Character Building $=62.5 \%$. With the existence of the data it can be concluded that the lowest score of the theory lesson is Character Building followed by Indonesian Language lesson. The highest score is in Audio-Visual lessons.

Next, the researcher tried to create a scenario by including Indonesian Language and Character Building lessons into the Audio-Visual film-making practice. It is intended for students to increase their score in Indonesian Language and Character Building through Audio and Visual practice. The results of Action 2 learned in Audio-Visual practice by pacing up Indonesian Language andCharacter Building increased as follows : Indonesian Language $=78.79$ (3 students did not pass), Audio-Visual $=88.12$ (1 student did not pass), Character building $=88.56$ (24 students passed). The percentage of students in Indonesian Language $=83 \%$, Visual Audio $=95.8 \%$, Character Building $=100 \%$. The results of action 2 indicate that the result have improved and that the learning process has changed a lot better than before. Based on the agreement between researcher and Indonesian Language, Audio-Visual, and Character Building teacher,the learning cycle discontinued. 
Table 2. Statistics Data

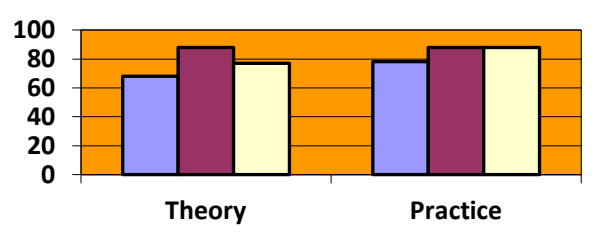

口Indonesian Language

口Audio Visual

口Char Build

Tabel 2. Repot Score

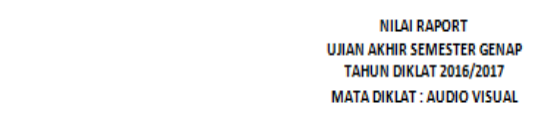

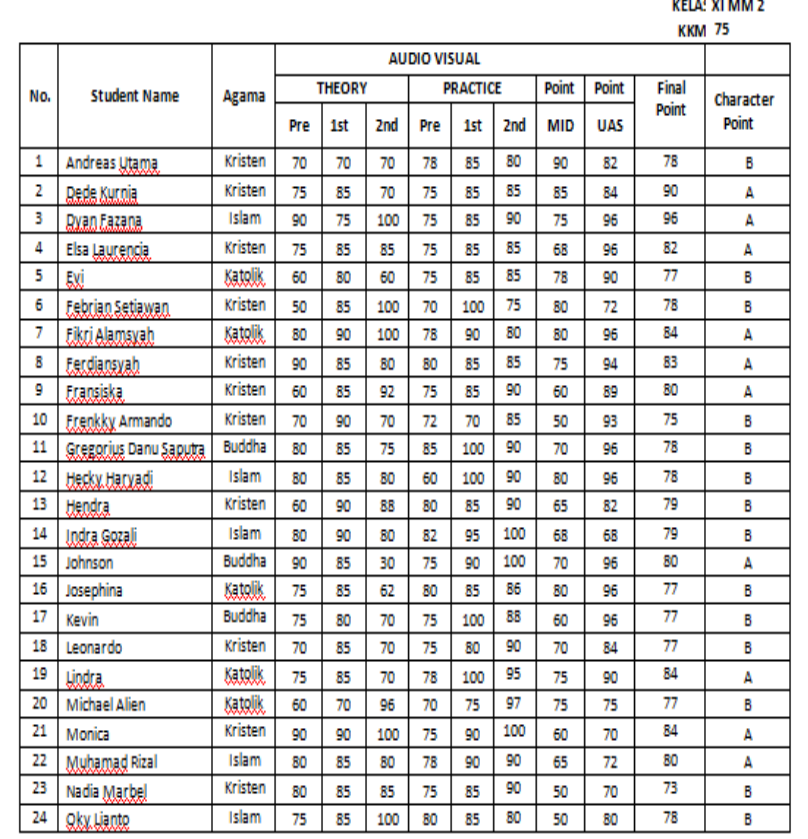

TOTAL : $1.655: 2.015: 1.913: 1.891: 2.1152 .126$

Bate point: $69,1: 85.68: 79.71: 78.79: 88.12 \quad 88.58$

Description :

Theory tests : 1st (Indonesian Language)

2nd (Audio Visual)

3rd (Character Building)

Practice

: 1st (Indonesian Language)

2nd ( Audio Visual)

3rd (Character Building)

Midterm exams and Final exams : Audio Visual

Table 4. Percentage of Increase in Learning Outcomes

\begin{tabular}{|c|c|c|c|c|c|c|c|c|c|c|c|}
\hline \multirow{3}{*}{\begin{tabular}{|l} 
No \\
\\
\end{tabular}} & \multirow{3}{*}{$\begin{array}{l}\text { Action } \\
\text { Pre Action }\end{array}$} & \multirow{3}{*}{$\begin{array}{l}\text { Number } \\
\text { of } \\
\text { Student }\end{array}$} & \multicolumn{6}{|c|}{ Score } & \multirow{2}{*}{\multicolumn{3}{|c|}{$\begin{array}{l}\text { Increase in average value } \\
\text { Ind.Lang Aud Vis Char Build }\end{array}$}} \\
\hline & & & \multicolumn{3}{|c|}{$\leq 75$} & & & & \\
\hline & & & 7 & 2 & 9 & 17 & 22 & 15 & $70.8 \%$ & $91.7 \%$ & $62.5 \%$ \\
\hline 2 & First Action & 24 & 4 & 1 & 0 & 20 & 23 & 24 & $83 \%$ & $95.8 \%$ & $100 \%$ \\
\hline 3 & $\begin{array}{l}\text { Increase } \\
\text { in average } \\
\text { value }\end{array}$ & 24 & 3 & 0 & 8 & 3 & 0 & 7 & $13 \%$ & $4.1 \%$ & $37.5 \%$ \\
\hline
\end{tabular}

\section{CONCLUSION}

The "three in one" model provides a new breakthrough to develop learning model in the form of practice that covers three fields of study in order to develop learning outcomes and achievements in the field of study while conducting character education. The assessment process of Indonesian Language material and religious education in filmmaking on visual audio subjects can be synergized with audio visual material. Filmmaking that contained the value of character education included religious values, tolerance, honesty, responsibility, and so on.

The test model three in one via the film visual audio learning media is that there is a higher relative increase in learning. In the pre-act (theory) of the academic participants have the percentage of Indonesian Language $=70.8 \%$, Audio Visual $=91 \%$, and Religion $=62.5 \%$. The result of action 2 in Audio Visual Practice with a percentage of completeness Indonesian Language $=83 \%$, Audio Visual $=95.8 \%$, Religion $=100 \%$. Through interviews and polls, $97 \%$ of the students like the video game-making which contain character values for effective, fun, and not boring reasons. A three-piece syntax model in video games is a learning strategy that can improve students' achievement and character development.

\section{REFERENCES}

Agus, Wibowo. (2012). Pendidikan Karakter Strategi Membangun Karakter Bangsa Berperadapan.Yogyakarta:Pustaka Pelajar

C. Crawford, (1984). "The Art of Computer Game Design," p. 134. Available at

http://www.mindsim.com/MindSim/Corporate/artCGD.pdf. Retrieved August 22019

DP Kristiadi, Y. Udjaja, B. Supangat et al. (2017). The effect of UI, UX and GX on video games, Proceedings of the 2017 IEEE International Conference on Cybernetics and Computational Intelligence (CyberneticsCom),March,12-03- IEEEXplore Pres, Phuket, Thailand,pp. 158-163, DOI : 10.1109/CYBERNETICSCOM.2017.8311702

Frank GB. (2016). The Word Has Become Game: Researching Religion in Digital Games. Online Heidelberg Journal of Religions on the Internet. 11: 28-45

H.L.H.S. Warnars, (2008). Game Information System. Proceedings of CGAMES 2008 - 12th International Conference on Computer Games: AI, Animation, Mobile, Educational and Serious Games, Louisville, Kentucky, USA.

K. Hinckley, K. Yatani, M. Pahud, N. Coddington, J. Rodenhouse, A. Wilson, H. Benko, and B. Buxton, (2019). "Proceedings of the 2010 ACM Symposium on User Interface Software and Technology," Pen touch = new tools, pp. 27-36, 2010. Available at http://doi.acm.org/10.1145/1866029.1866036 Retrieved August 22019

K. Salen and E. Zimmerman, (2004). "Game Design Fundamentals," Rules of Play: Game Design Fundamentals.

Kemendiknas. (2011). Panduan Pelaksanaan Pendidikan Karakter.Jakarta: Kemendiknas

Kristiadi DP, et al (2019). The Effect of Adventure Video Games on the Development of Student's Character and Behavior, IJEVS.Vol.1 No.4.2019

Kristiadi DP, Y. Udjaja, B. Supangat et al. (2017). The effect of UI, UX and GX on video games, Proceedings of the 2017 IEEE 
International Conference on Cybernetics and Computational Intelligence (CyberneticsCom),March,12-03- IEEEXplore Pres, Phuket, Thailand, pp. 158-163,

Kristiadi, Y. Udjaja, B. Supangat et al. (2017). The effect of UI, UX and GX on video games, Proceedings of the 2017 IEEE International Conference on Cybernetics and Computational Intelligence (Cybernetics Com), March, 12-03- IEEEXplore Pres, Phuket, Thailand,pp. 158-163.

Lickona, Thomas. (2004). "Make Your School A School of Character". dalam Character Matters. www.Cortland.edu/character. Retrieved August 4, 2019

M. Hassenzahl, (2004). "The Thing and I: Understanding the Relationship between User and Product," Funology: From Usability to Enjoyment, pp. 31-42.

Richard EF. (2014). Developing a Framework for Understanding the Relationship between Religion and Videogames. Online Heidelberg Journal of Religions on the Internet. 5: 68-85

Ririn DA, Ayu P, Kridanto S, Iping SS. (2015). Computing Game and Learning State in Serious Game for Learning. TELKOMNIKA (Telecommunication Computing Electronics and Control). 13(4): 1422-1436

Robert MG. (2012). Theological Productions: The Role of Religion in Video Game Design. In: Adam LB, Natacha G. Editors. Cultural Perspectives of Video Games: From Designer to Player. London: Oxford Inter-Disciplinary Press; 2012: 101-114

Sanjaya, Wina. (2012). Perencanaan dan Desain Sistem Pembelajaran. Jakarta: Kencana Prenada Media Group

Sudjana, Nana. (2010). Penilaian Hasil Proses Belajar Mengajar. Bandung : PT. Remaja Rosdakarya Offset

Trianto. (2011). Panduan Lengkap Penelitian Tindakan Kelas (Classrooom Action Research). Surabaya: Prestasi Pustakaraya

UU RI No. 20 TAHUN 2003 tentang SISTEM PENDIDIKAN NASIONAL

sindikker.dikti.go.id/dok/UU/UU20-2003-Sisdiknas .pdf Retrieved August 42019

Wagiran. (2010). Implementasi Pendidikan Karakter dalam Menyiapkan Tenaga Kerja Kejuruan dalam Menghadapi Tantangan Global. Makalah Penelitian pada Prosiding Seminar Nasional dalam Rangka Dies Natalis ke-46 UNYbulan Mei 2011. http://staff.uny.ac.id/sites/default/files/132297916/makalah\% 20seminar\%20 nasional.pdf Retrieved August 52019.

Warnars HLHS. (2008). Game information System. Proceedings of CGAMES 2008 - $12^{\text {th }}$ International Conference on Computer Games: AI, Animation, Mobile, Educational and Serious Game. Louisville, Kentucky, USA. 2008. 